\title{
ディスクタイプ押出機に関する基礎的研究
}

\author{
船津和守 ${ }^{* 1} \cdot$ 梶原稔尚 ${ }^{* 1} \cdot$ 美濃田武 ${ }^{* 2} \cdot$ 大賀美範 $^{* 3}$
}

\section{Basic Study on Disk Type Extruders}

\author{
Kazumori Funatsu, Toshihisa Kajiwara, Takeshi Minoda \\ and Yoshinori OHgA
}

\begin{abstract}
Although screw extruders have been used for the production of films, pipes, sheets and many other kinds of plastic products, there is still room for improvement. The melting process has an important role in extruders. According to the results of computer simulations on the melting process in a single screw extruder, the melting ate of a polymer solid bed will increase strongly if the heat transfer surface can be enlarged. For ordinary screw extruders, it is very difficult to increase the heat transfer surface using the conventional screw geometry. Therefore, a disk type extruder was assembled as a modification to a single screw extruder. A trial apparatus was examined from various aspects. In this disk type extruder polymeric materials flow by relative motion between a fixed spiral plate where a rectangular channel was cut spirally from the center to the circumference and a moving flat plate. Usage of two surfaces of these plates for heating was very effective in increasing the melting rates. The extruder could extrude materials at rates less than $95 \mathrm{~g} \cdot \mathrm{min}^{-1}$ and under pressures less than 9.5 MPa. At higher pressures, the extruder developed leaks through the circumference. The leakage could probably be prevented by cooling the first turn of the channel sufficiently to keep the materials from melting. From the residence time distribution measured under steady extrusion, it was clear that there is circulation flow over flights. Mixing may thus be enhanced by longer shear loading by circulatory flow in the extruder.
\end{abstract}

Key words : Disk type extruder/Melting process/Mixing/Residence time distribution

\section{1. 緒 言}

プラスチック成形加工プロセスの中で多数の押出 機，とくに最近では二軸押出機が多数用いられてい るが，単軸押出機でも改良の余地は十分あると思わ れる. 単軸, 二軸押出機でも本体の中での材料の溶

\footnotetext{
*1 九州大学工学部化学機械工学科 福岡市東区箱崎 6-10-1 (

*2 三井石油化学工業(株)機能材研究所 千葉県君津郡袖ケ浦町長浦字拓 2 号 (テ 299-02)

*3 マツダ(株)技術開発本部 広島県安芸郡府中町新地 3-1 ( 7 730-91) 1989.2.14 受理
}

融過程はかなり長く，これを短くできれば押出機を もっとコンパクトにできるものと思われる，そこで本 報告ではまず，単軸押出機に関する Tadmor のシ ミュレーション手法"1)参考にし, 計算過程の細部に 工夫をして溶融過程の計算を行った. これらの計算結 果と実験結果を比較してシミュレーションの信頼性を 検証するとともに，溶融過程に及ぼす装置条件，操作 条件の影響を検討した，その結果，溶融過程を短くす る方法の 1 つして, 伝熱面積の増大が示唆された. ホッパーの近傍は冷却して材料の巻き込みが十分行わ れる領域を保障し，その領域を離れると材料の加熱を 開始できることを考慮した上で，スクリニーの加熱を 
行觉ば溶融過程を短縮できることが考えられる．しか し，スクリュー側から大きな熱量を与えるとホッパー 下の温度も上がり，材料の巻き込みが不十分になる. また，ホッパー近傍と計量部の間に断熱材を入れると 断熱材の強度がもたない.このよらにスクリュー押出 機では伝熱面積を増大させることが構造上難しい. そこで，加熱・冷却がスクリュー押出機よりも行い やすいと予想されるディスクタイプ押出機を検討し た.

ディスクタイプ押出機は単軸スクリュー押出機 の延長線上に位置し，スクリューの代わりに，チャン ネルがスパイラル状に彫られた平板（スパイラルプレ ート）を，バレルの代わりにフラットな平板（フラッ トプレート）を対応させ，これらの相対回転運動によ って材料を輸送すると同時に両平板の外面から加熱を 行うことができるものである.これまでも，各種のも のがディスクタイプ押出機と呼ばれてきた．例えば Maxwell らのスクリューレス押出機2), ディスク状 回転円板の表面に各種突起物を設けた装置 ${ }^{3), 4)}$ ，円板 の両面に互いに逆向きのスパイラル状に彫られたチャ ンネルを有する装置5)，わずかな角度を有する円錐に 2 条のチャンネルをスパイラル状に 彫った装置6)，考 方は異なるが Tadmor らのディスクパック7),など が提案されているが，性能の解明はほとんどなされて いない. そこで， 3 台の試作機を製作し，装置工学的 改良を行うとともに, 溶融過程, 押出特性, 滞留時 間分布，混練について検討を行った。

\section{2. 単軸押出機における溶融過程の解析}

\section{1 計算機シミュレーションの概要}

押出機 中の溶融過程, 溶融物の流動状態, 圧力分 布などを把握することは，生産の高速化，機械の大型 化・自動化，製品の高品質化を進める上で是非必要な ことである. 今回取り扱う溶融過程の計算について幾 つかの工夫を行ったが，これについては，これまで数 多くの紹介がなされているので, 計算手法は省略し, 得られた結果を提出し検討する.

押出機シミュレーション用モデルは Tadmor \& Klein ${ }^{1)}$, Chung ${ }^{8)}$, Donovan ${ }^{9)}$ ，などによって提案され ているが, Tadmor の手法を参考にし，プログラムを 開発した. また，固体輸送の計算は摩擦係数のデータ が不足しているため今回は行わず，押出流量の值は 与えた. 今回のシミュレーションの目的は材料の溶融 に必要な長さを検討することであるが，単軸 押出機 中の溶融機構についてはよく紹介されている6) ので説 明は省略する.

計算に用いたポリエチレン（HDPE 1）の物性を以
下に示す. 固体の密度, 比熱は各々 $9.50 \times 10^{-4} \mathrm{~kg}$. $\mathrm{m}^{-3}, 2.43 \mathrm{~kJ} \cdot \mathrm{kg}^{-1} \cdot \mathrm{K}^{-1}$, 溶融物の密度, 比熱は各々 $7.60 \times 10^{-4} \mathrm{~kg} \cdot \mathrm{m}^{-3}, \quad 2.97 \mathrm{~kJ} \cdot \mathrm{kg}^{-1} \cdot \mathrm{K}^{-1}$ ，熱伝導度は $1.04 \times 10^{-6} \mathrm{~W} \cdot \mathrm{m}^{-1} \cdot \mathrm{K}^{-1}$, 融解熱は $132.7 \mathrm{~kJ} \cdot \mathrm{kg}^{-1}$, 融 点は $129^{\circ} \mathrm{C}$ である. さらに粘度 $\eta(\mathrm{Pa} \cdot \mathrm{s})$ は温度 $T$ $\left({ }^{\circ} \mathrm{C}\right)$, 剪断速度 $\dot{\gamma}\left(\mathrm{s}^{-1}\right)$ で次式のように表される. $\ln \eta=1.309548 \times 10-1.222893 \times 10^{-1} \ln \dot{\gamma}$

$$
-6.316352 \times 10^{-2}(\ln \dot{\gamma})^{2}-1.883408 \times 10^{-2} T
$$$$
+1.851759 \times 10^{-5} T^{2}+1.242736 \times 10^{-3}(\ln \dot{\gamma}) T
$$

\section{2 実験結果と計算結果の比較検討}

\section{a . 実験装置および方法}

押出機のバレル直径は $40 \mathrm{~mm}$ で，その先端に直 径 $4 \mathrm{~mm}$, 長さ $40 \mathrm{~mm}$ のノズルが取り付けられた。 Fig. 1 に冷却実験に用いたスクリューのみを示した. 直径 $40 \mathrm{~mm}$ である. テーパ部はホッパーから 9 から 15 ターンである. バレルには熱電詨と圧力タップが 設置された。実験はバレル温度が約 $180^{\circ} \mathrm{C}$ から約 $230^{\circ} \mathrm{C}$ の範囲で 3 レベル, スクリュー回転数は 30 , $50,70 \mathrm{~min}^{-1}$ で行った. 冷却実験, 固体床幅 $X$ の測 定は通常の方法によった.

\section{b. 固体床分布の実験結果亡計算結果の比較}

Figs. 2, 3 に各々, バレル温度 $T_{b}$ の分布が等し く, 流量 $G$ (回転数 $N$ ) を変えた場合の比較を示し た. 溶融開始点は理論的推定がまだ困難であるので実

[SCREW-I]

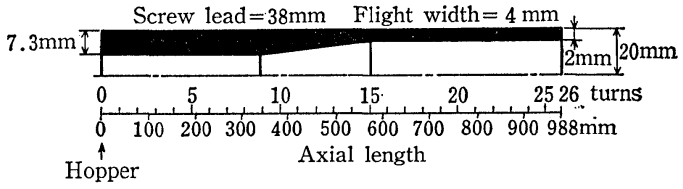

Fig. 1 Screw geometry in a single screw extruder for cooling experiment

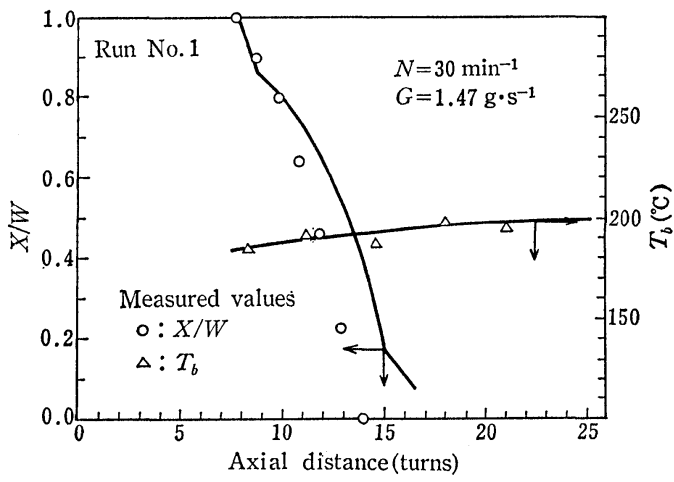

Fig. 2 Comparison between simulated and experimental values of solid bed profile at $30 \mathrm{~min}^{-1}$ in screw rotation 


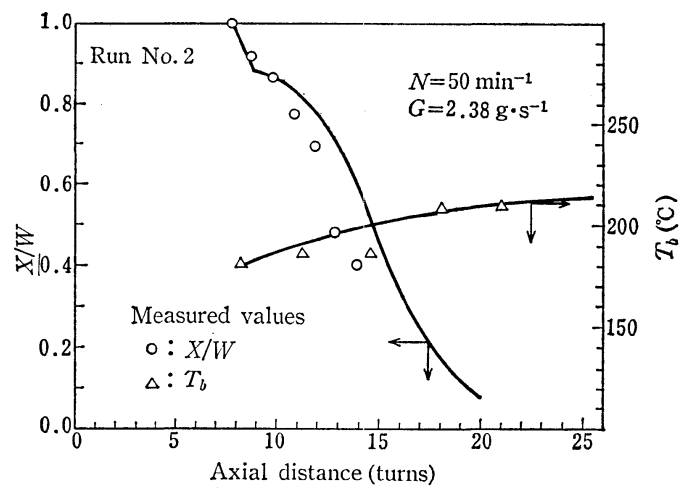

Fig. 3 Comparison between simulated and experimental values of solid bed profile at $50 \mathrm{~min}^{-1}$ in screw rotation

験值を与えた：溶融初期の溶融速度の予測はできてい るが，テーパ部に入って溶融速度の実測值に顕著な変 化が現れないのは，計算上仮定されているよらにテー パ部に入って固体床が圧縮されてその幅が大きくなら ないためであるままた，溶融完了までの長さが計算值 で大きくなるのは，計算上の仮定に反し，スクリニー ルートやメルトプールからの伝熱がかなりあるためで ある. 実際には固体床がある程度小さくなると床の形 がばらばらにされるが，この作用は計算に含まれてい ない.

以上の検討から，今回の計算手法は溶融過程を注ぽ 予測できることがわかったので，計算条件を拡張して 結果を求め, 溶融過程をより一般的に考察する.

2.3 広い条件での固体床分布の計算結果亡 その考察

計算に使用したスクリュー形状は Fig.1 のものを

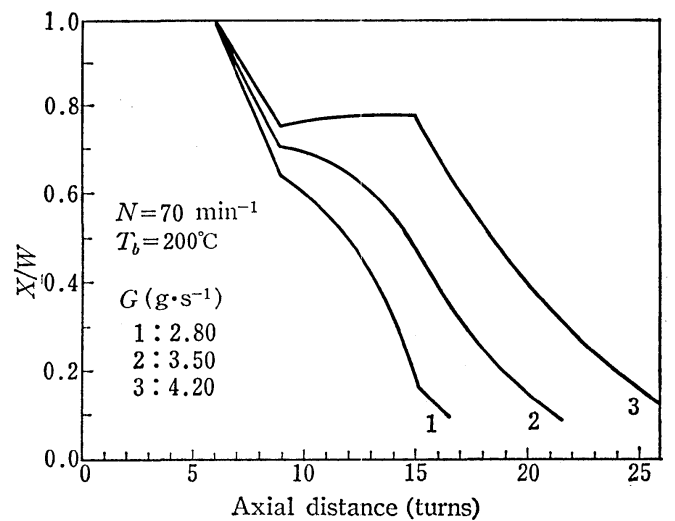

Fig. 4 Simulated solid bed profiles dependent upon variation in flow rate

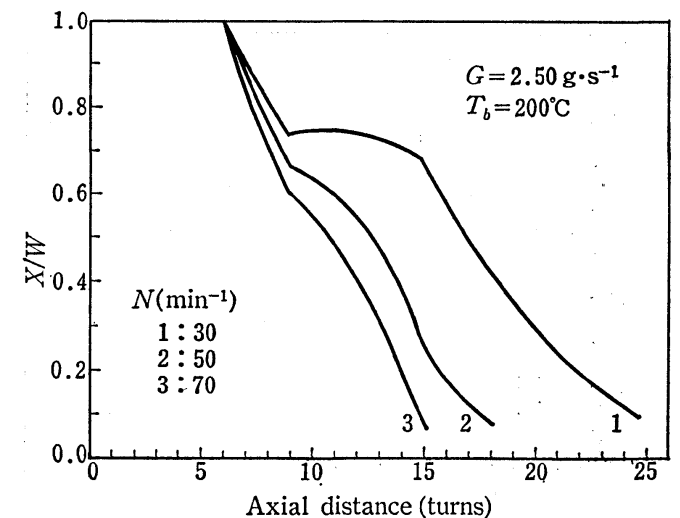

Fig. 5 Simulated solid bed profiles dependent upon variation in screw rotation

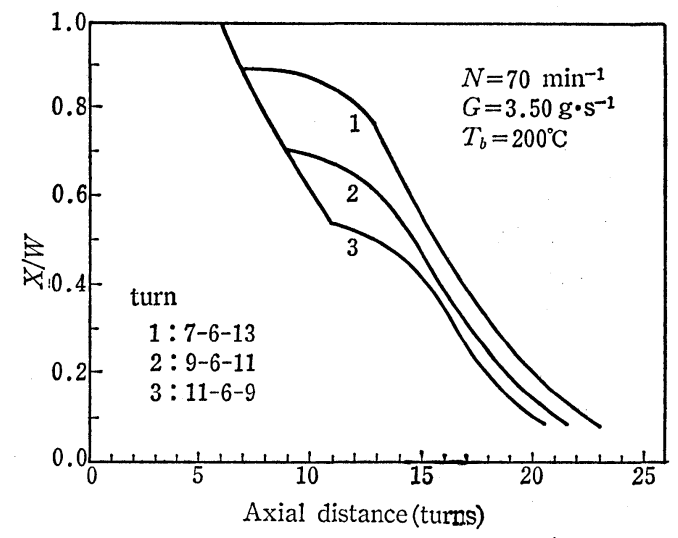

Fig. 6 Simulated solid bed profiles dependent upon change in position of compression zone

基本とした．まず，図には示していないがバレル温度 が $180^{\circ} \mathrm{C}$ では溶融完了まで 25 ターン以上必要になる 場合もあり, 問題である. Fig. 4 亿示した, バレル温 度, 回転数を一定にし，押出流量を变化させた場合 の固体床分布では，流量が大きくなると未溶融材料が 流出する可能性を表している. Fig. 5 と示した, バレ ル温度, 押出し流量を一定にし, 回転数を変化させた 固体床分布は高い回転数で早く溶融することを表して いる.これは高回転数による溶融フィルム中に発生す る大きな粘性発熱量が原因である。このように粘性発 熱量も溶融に大きな影響を与兄る. Fig. 6 に示すテー パ部 (圧縮部) の位置の相違の影響では, テーパ部が ホッパーに近い程初期の溶融速度は遅く, 溶融完了は 遅れるが，この程度の条件ではその差は小さい.Fig. 7 によると固体供給部長さは一定で，テーパ部と計量 部の長さを短縮すると，前述したようにテーパ部に入 


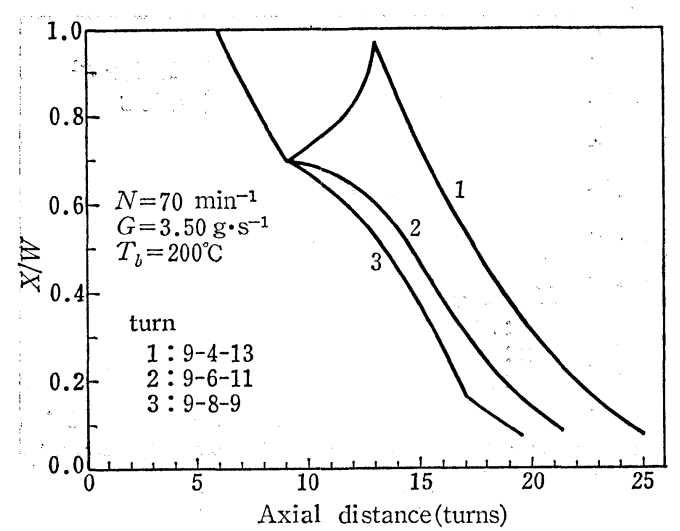

Fig. 7 Simulated solid bed profiles dependent upon change in length of compression and metering zones

った固体床は圧縮され，その幅が再び広げられるた め，これが計算上溶融速度を小さくする.

以上の計算結果をみると，単軸押出機の、操作条 件, 装置条件を幅広く変えても溶融過程をかなり短く することは難しいといえる．これを実現するために は，別の付加的な因子を考慮することが考光られる. 実験の溶融速度が計算值に比べて大きくなる場合はス クリニールートやメルトプールからの伝熱が効いてい ることから考えて，溶融過程を短くする 1 つの方策と して伝熱面積の增大が有効であることが示唆される. 緒言で述べたように，スクリュ一押出機でこれを実 施するのは困難であると思われるので, 前述したディ スクタイプ押出機を検討することにした.

\section{3. ディスクタイプ押出し機}

\section{1 装置の特徵}

ディスクタイプ押出機 の特徵は, (1) 構造が簡単で 製作が比較的容易である, (2) プレート両面を伝熱面に 使える, (3)ディスク半径が小さくても，チャンネル長 さを比較的長くできる，などである. 欠点は, (1) 2 板 のプレートのクリアランスからの漏れ防止に工夫を要 する，(2)押出圧力を高くできない，(3)架台，押出 機本体の剛性を十分高くする必要がある，などであ る.

\section{2 実験装置}

装置全体図を Fig. 8 亿示す. ホッパー (1) から入っ た材料は固定したスパイラルプレート (2) の外周に供 給され、フラットプレート (3) の回転によって中心方 向に輸送される.さらに, 両プレートに取り付けたヒ ーターで加熱・溶融され，ノズル (10)を通して押し出

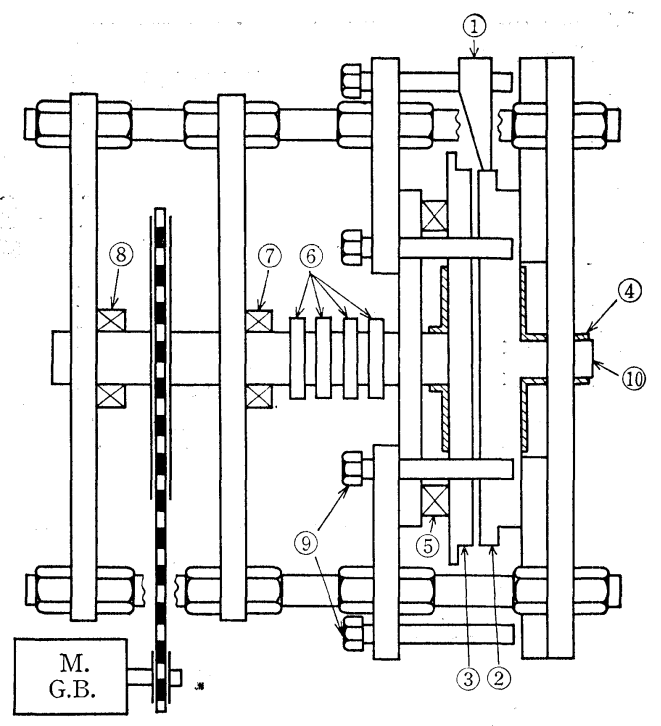

(1) Hopper, (2) Spiral plate, (3) Flat plate,

(4) Heater, (5) Thrust bearing, (6) Slip ring,

(7) Radial bearing, (8) Radial bearing,

(9) Stopper bolt, (10) Nozzle

Fig. 8 Experimental apparatus of disk type extruder

される. 本装置の機構では両プレート間に発生する大 きな圧力に耐えるために架台，押出機本体は十分な 剛性と強度を持ち, また十分大きなスラストベアリン グが必要である. (9)のストッパーは内部の圧力が低 下した場合に両プレートの接触を防止する.

次に，両プレートを Fig. 9 に示す. No. 3 スパイラ ルプレートは外径 $280 \mathrm{~mm}$ で, Fig. 10 に示す形状の チャンネルを持つ. チャンネル深さ $h$ は, 背圧があま り負荷されず, 出口に向かって溶融物をスムースに流 動させるため, $r h=$ 一定 $(r$ : 中心からの距離) に保つ 值とした. また, フラットプレートの外周部には材料 を末溶融状態に保つため断熱材を挿入し，かつ材料の 送りをよくするために表面に溝を切った．Fig.10 に はまた, 供給部, 圧縮部, 計量部の大体の区分を示し た. チャンネルの全長は $1480 \mathrm{~mm}$ である. 直径 40 $\mathrm{mm}$ の単軸押出機用スクリニ一のそれは約 1800 $\mathrm{mm}$ で, 両者はほぼ等しい。

温度は Fig. 9 に示す測定点で, (1): $90 \sim 105^{\circ} \mathrm{C}$, (2) : $118 \sim 128^{\circ} \mathrm{C}$, (3) $: 129 \sim 138^{\circ} \mathrm{C}$, (4) : $142 \sim 162^{\circ} \mathrm{C}$, (5) : $145 \sim 152^{\circ} \mathrm{C}$, (6) : $162 \sim 170^{\circ} \mathrm{C}$, (7): $160 \sim 170^{\circ} \mathrm{C}$, ノズル：182〜184 ${ }^{\circ} \mathrm{C}$ に制御された.この際スパイラ ルプレートの外周部は冷却された.

\section{3 実験方法}

試料は前と同様に HDPE 1 を用いた。 冷却ジャケ 


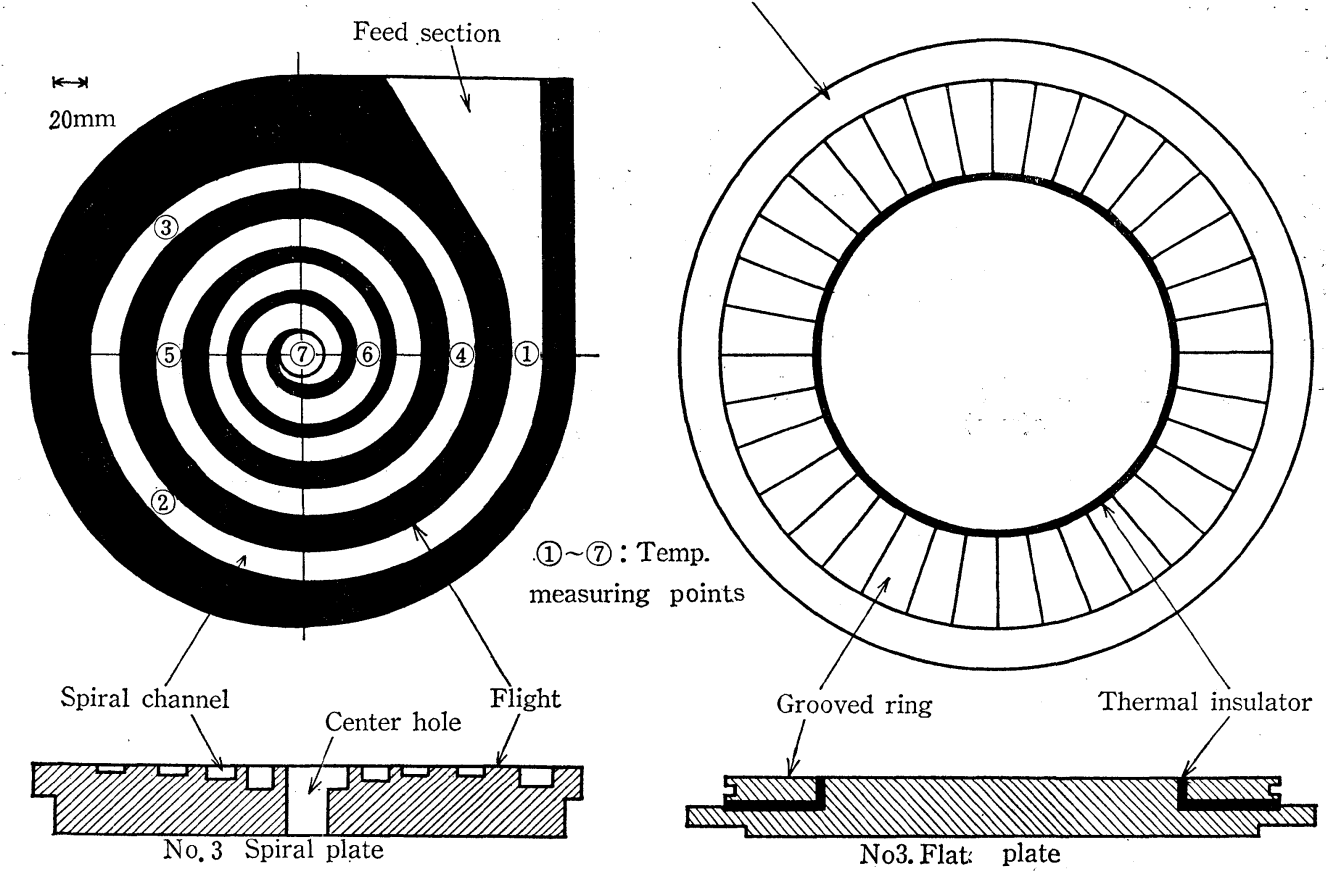

Fig. 9 Geometry of spiral plate and flat plate

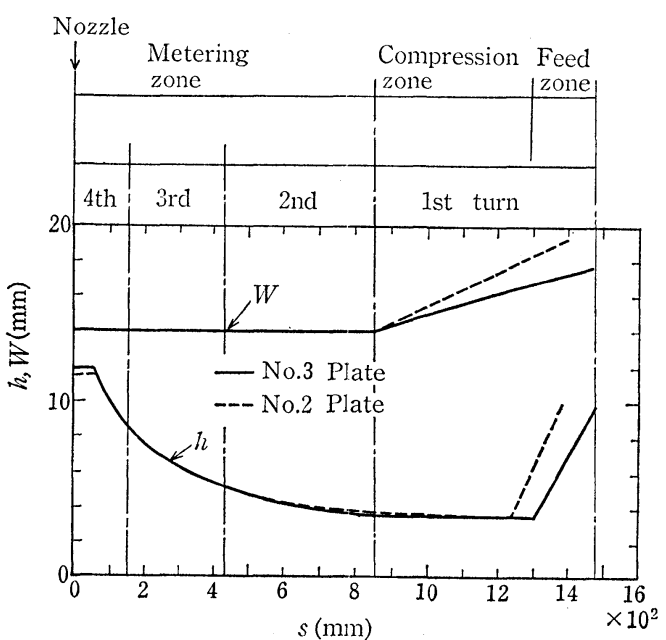

Fig. 10 Variation of channel depth $h$ and channel width $W$ along channel length $s$

ットにはクリアランスからの漏れが止まる最低流量の 水を流した， 2 個のダイヤルゲージにより，設定され たクリアランスの值には架台, プレートなどの製作精 度や剛性が不十分なための変形によってかなりの誤差 が入っているものと思われる。

\section{4 実験結果}

まずクリアランス $\delta_{f}$ が押出流量に及ぼす影響を

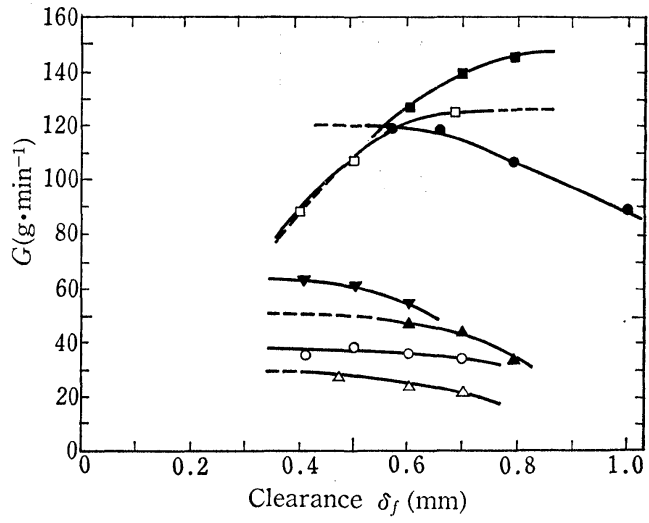

\begin{tabular}{|c|c|c|c|c|}
\hline & $D(\mathrm{~mm})$ & $L(\mathrm{~mm})$ & $N\left(\min ^{-1}\right)$ & Sample \\
\hline$\square$ & \multirow{2}{*}{\multicolumn{2}{|c|}{ Free discharge }} & 25 & \multirow{4}{*}{ HDPE 1} \\
\hline $\mathbf{a}$ & & & 30 & \\
\hline 0 & \multirow{2}{*}{6} & \multirow{2}{*}{15} & 10 & \\
\hline 0 & & & 30 & \\
\hline$\triangle$ & \multirow{3}{*}{6} & \multirow{3}{*}{30} & 10 & \multirow{3}{*}{ HDPE 2} \\
\hline$\Delta$ & & & 20 & \\
\hline$\nabla$ & & & 25 & \\
\hline
\end{tabular}

Fig. 11 Dependence of extrusion rate upon clearance 


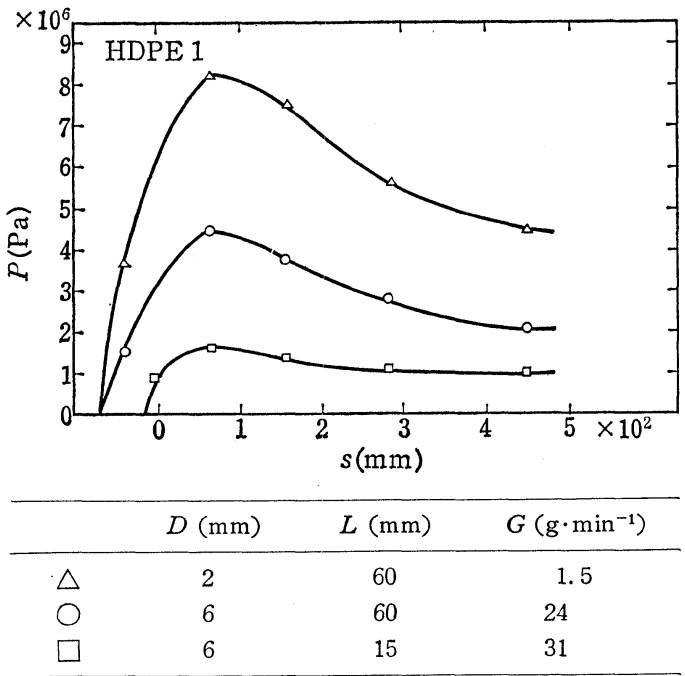

Fig. 12 Pressure distributions along channel

Fig. 11 に示す. この程度の回転数では $\delta_{f}$ を大きく すると流量はわずかに低下する．しかし，ノズルを付 けない場合 (free discharge) に $\delta_{f}$ を大きくすると大 幅に流量が増加する．これは溶融物を出口に送るのに

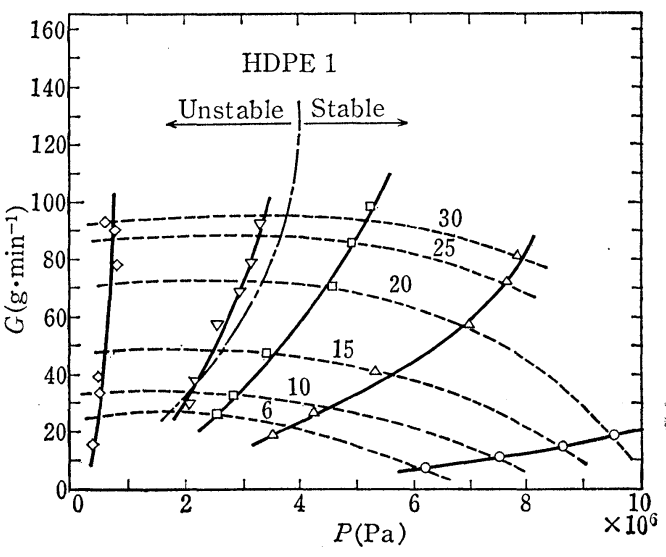

\begin{tabular}{ccc}
\hline \multirow{2}{*}{ Key } & \multicolumn{2}{c}{ Nozzle } \\
\cline { 2 - 3 } & $L(\mathrm{~mm})$ & $D(\mathrm{~mm})$ \\
\hline$\triangle$ & 60 & 4 \\
$\square$ & 60 & 6 \\
$\nabla$ & 30 & 6 \\
$\diamond$ & 15 & 6 \\
\hline
\end{tabular}

$\delta_{f}=0.4 \mathrm{~mm}$

Fig. 13 Relation between extrusion rates and the maximum pressures

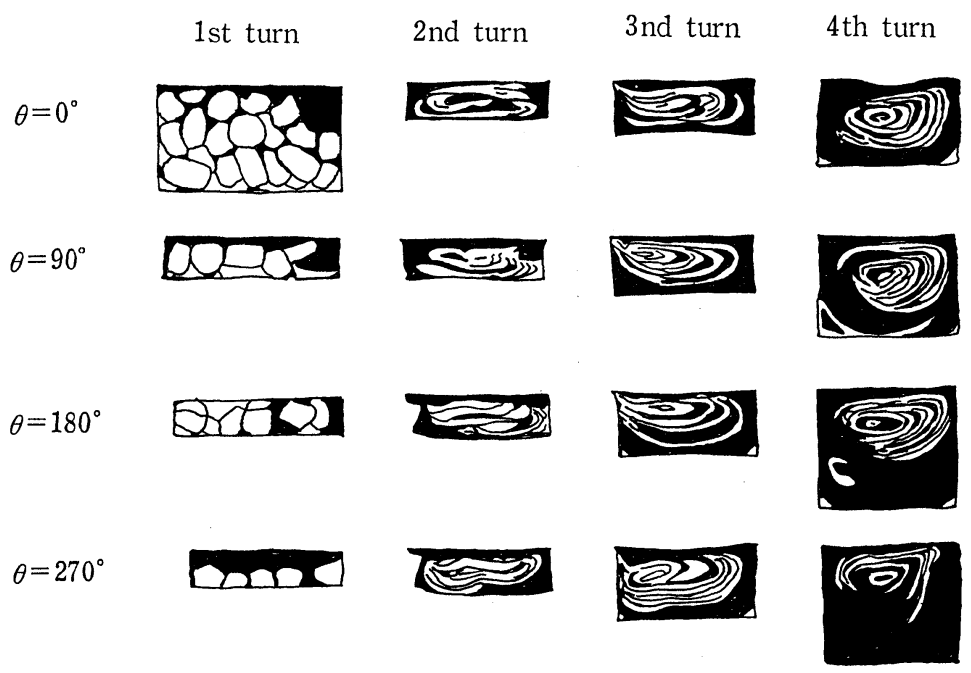

Low $\longleftarrow$ Pressure $\longrightarrow$ High

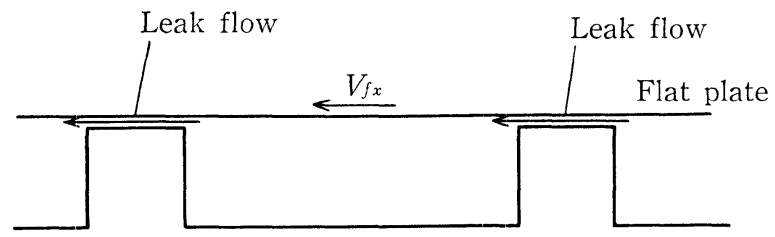

Spiral plate

Fig. 14 Schematic cross sections (HDPE 1) obtained from cooling experiment $N=10 \mathrm{~min}^{-1}, \quad G=29.0 \mathrm{~g} \cdot \mathrm{min}^{-1}, L=60 \mathrm{~mm}, D=6 \mathrm{~mm}, P=4.86 \times 10^{6} \mathrm{~Pa}$ 


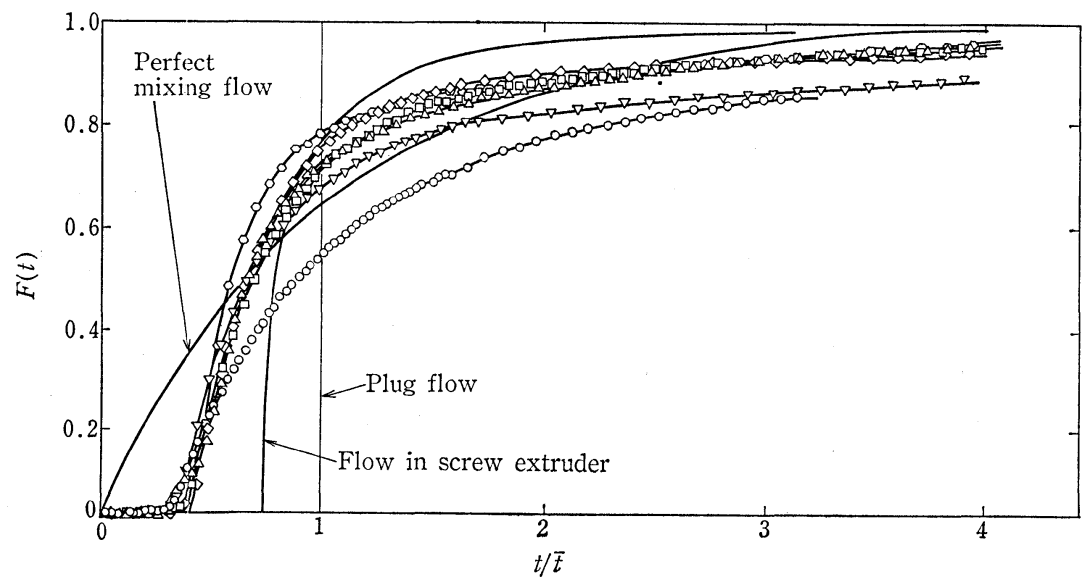

HDPE $1, \delta_{f}=0.4$

\begin{tabular}{cccccc}
\hline & \multicolumn{2}{c}{ Nozzle } & $N\left(\min ^{-1}\right)$ & $\bar{t}(\mathrm{~s})$ & $G\left(\mathrm{~g} \cdot \mathrm{min}^{-1}\right)$ \\
\cline { 2 - 3 } & $L(\mathrm{~mm})$ & $D(\mathrm{~mm})$ & & & \\
\hline$\bigcirc$ & 60 & 4 & 10 & 767 & 10.9 \\
$\triangle$ & 60 & 6 & 10 & 315 & 28.2 \\
$\square$ & 60 & 6 & 20 & 217 & 49.2 \\
$\nabla$ & 60 & 6 & 30 & 182 & 67.7 \\
$\diamond$ & 30 & 6 & 20 & 184 & 61.2 \\
$\square$ & 15 & 6 & 20 & 170 & 73.0 \\
\hline
\end{tabular}

Fig. 15 Residence time distribution function $F(t)$ versus reduced time $t / t$ under various extrusion conditions ( $\bar{t}$ : Mean residence time)

抵抗が弱まるためである。ノズルによる流動抵抗があ る場合に流量を增加するためには逆流を減少させるた め, $\delta_{f}$ はでさるだけ小さくする. 次に, チャンネルに 沿って測定した圧力分布 (Fig.12) によると, チャン ネル出口付近で最大圧力が発生するが，単軸押出機 の多くの場合最大圧力が圧縮部終端から計量部初期に 発生するのとは異なっている. Fig.13 に回転数と, ズルをパラメータにして最大圧力と流量の 関係を示 す. 圧力が低い領域では流量の変動が大きく不安定で あったが， ある值以上になると安定した押出状態で あった. この原因は, 流動が持つ特性でなく形状とく にクリアランスの安定性なども関係すると思われるの で，現在のところ不明である。また，同一ノズルで高 、回転数では, 圧力の低い範囲では圧力によらず流量 は一定となるが，高い圧力では発生する逆流のため流 量は減少することがわかる.さらに, 圧力が $9.5 \mathrm{MPa}$ 程度むで㤞定して押し出せるが，これ以上の性能を 得るためには駆動力, 架台などについて大幅な改造が 必要である. 同一ノズルで大流量になると材料の非ニ ニートン性のため右上がりの曲線となることもわか る. Fig. 14 飞冷却実験で得られたチャンネル断面の 溶融経過の一例を示す. 角度 $\theta\left(^{\circ}\right)$ は Fig. 9 のホッパ
一出口断面を基点としたものである．眓中黒く塗りつ ぶした所は溶融してトレーサー色素が混入している. 外周から第 1 ターンでは冷却を効かして材料を未溶融 状態に保とうと試みているが，フラットプレート側に は冷却ジャケットを付けてないので溶融が進んでい る. 第 2 ターン以降は, 両面伝熱の効果が現れている ことが流線パターンの形からわかる. しかし，第 4 タ ーンになると深いチャンネルで循環が悪いことがわか るので, チャンネルの幅と深さは今後の課題である. ここでは，一例を示したが，ディスクタイプ押出機 の両面加熱の有効性は他の例でも十分証明された．し かし，フラットプレートでも第 1 ターン付近は冷却を 行うべきである。このためにはディスク（プレート） 形状を工夫し，かつ断熱を効果的に用いる工夫が必要 である. 次に材料の混練の目安となる可能性を持つ滞 留時間分布を Fig. 15 に示す. 滞留時間分布は, ホッ パーにトレーサーとして砂粒を所定量だけパルス状に 投入し, 出口で測定された砂粒の質量の時間経過のデ 一タから計算された，まず，装置内で滞留がないと仮 定した場合の平均滞留時間は, 装置体積を体積流量で 割って得られる. 質量流量が $49.2 \mathrm{~g} \cdot \mathrm{min}^{-1}, 73.0 \mathrm{~g}$. $\min ^{-1}$ について各々 $178 \mathrm{~s}, 120 \mathrm{~s}$ となったが, これら 


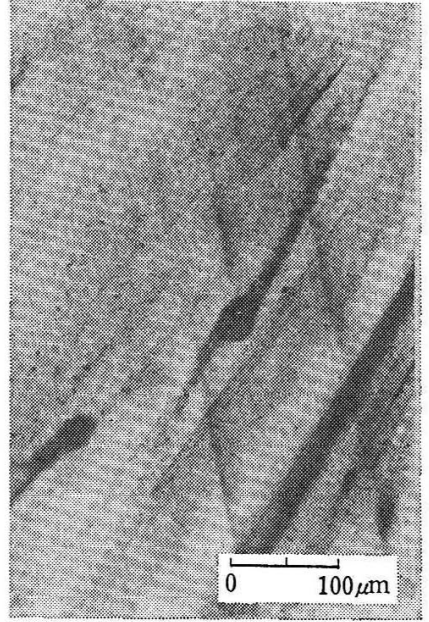

$10 \mathrm{~min}^{-1}$

$G=27.9 \mathrm{~g} \cdot \mathrm{min}^{-1}, \quad P=4.62 \times 10^{6} \mathrm{~Pa}$

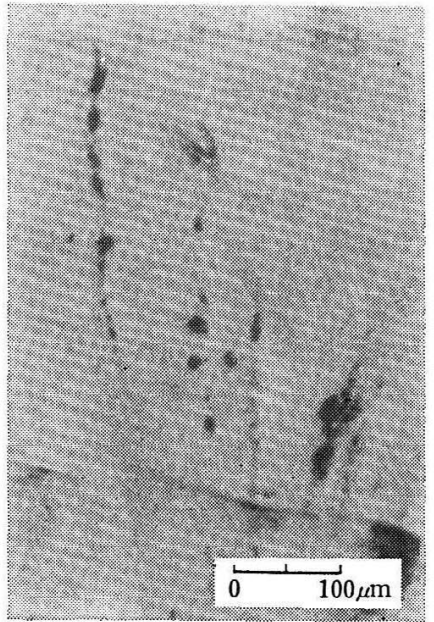

$20 \mathrm{~min}^{-1}$

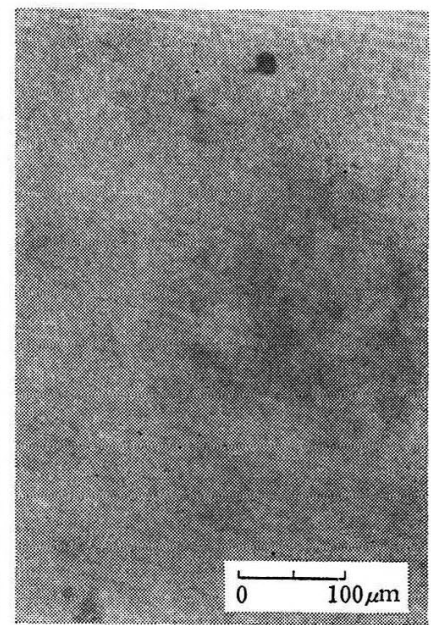

$30 \mathrm{~min}^{-1}$

$G=38.7 \mathrm{~g} \cdot \mathrm{min}^{-1}, \quad P=5.34 \times 10^{6} \mathrm{~Pa} \quad G=30.2 \mathrm{~g} \cdot \mathrm{min}^{-1}, \quad P=4.66 \times 10^{6} \mathrm{~Pa}$

Nożzle $L=60 \mathrm{~mm}, D=6 \mathrm{~mm}$

Fig. 16 (a) Change of mixing patterns of agglomerated carbon black in HDPE 1 extrudated through the same nozzle under various extrusion rates

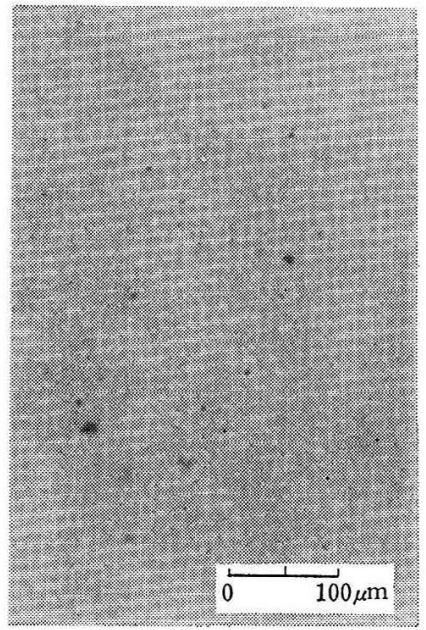

$L=60 \mathrm{~mm}, D=4 \mathrm{~mm}$

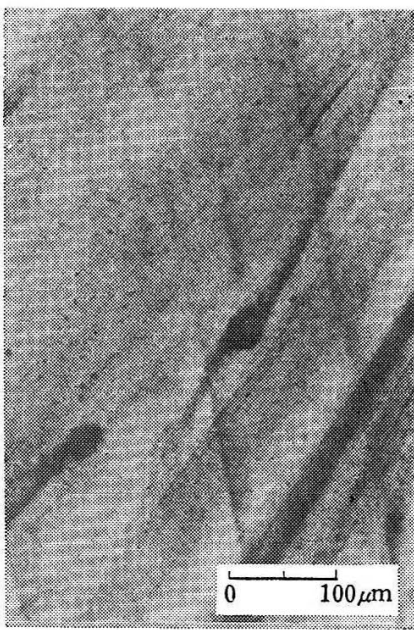

$L=60 \mathrm{~mm}, D=6 \mathrm{~mm}$

$G=27.9 \mathrm{~g} \cdot \mathrm{min}^{-1}, P=4.62 \times 10^{6} \mathrm{~Pa}$

$N=10 \mathrm{~min}^{-1}$

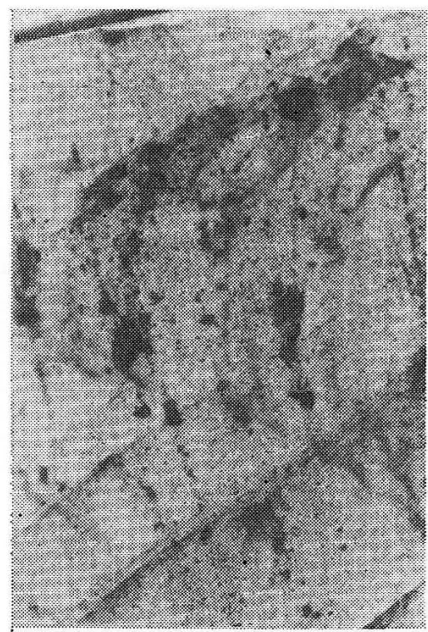

$L=30 \mathrm{~mm}, D=6 \mathrm{~mm}$

$G=32.1 \mathrm{~g} \cdot \mathrm{min}^{-1} \quad P=3.21 \times 10^{6} \mathrm{~Pa}$

$G=12.4 \mathrm{~g} \cdot \mathrm{min}^{-1}, P=7.76 \times 10^{6} \mathrm{~Pa}$

Fig. 16 (b) Change of mixing patterns of agglomerated carbon black in HDPE 1 extrudated through various nozzles at the same rotational speed

に比べ図中の真の平均滞留時間は各々 $217 \mathrm{~s}, 170 \mathrm{~s}$ と かなり長いことから循環流の存在が予想される。これ は, チャンネル出口付近で発生する最大圧力によって 上流側にフライトを越える逆流の発生が考兄られるこ とから納得される. この逆流の存在はチャンネル断面 の流線パターンからもらなずける. 通常循環流のない
単軸スクリニー押出機の場合, 図上り明らかなよう に，投入されたトレーサーが出口に最初に現れる時間 は平均滞留時間の $3 / 4$ となるが，本装置における平 均滞留時間が長いので無次元化したトレーサー流出開 始時間は小さくなる傾向にある.このような状況から 材料が受ける全剪断量はそれだけ多くなるため混練は 
よくなると予想される．混練をカーボンブラックの分 散状態で大略評価したのが，Figs.16 (a)，（b ）であ る.（a）には, 同一ノズルであれば高回転数の場合が 分散がよいこと，（b）には，回転数が一定では，最大 圧が高い，つまり循環流が発生する場合に分散がよい ことを示す．混練の程度を定量的伻価できる可能性 を持つ滞留時間分布関数㳊䦥する詳細な検討は今後の 重要な課題である.

\section{4. 結 言}

まず単軸スクリュー押出機のシミュレーションの 計算結果から溶融過程を短くするためには, 伝熱面の 増大が有効であるとの示唆が得られた. この方法の 1 つとして着想されたディズクタイプ押出機に関し実 験的検討を行い，以下のことが明らかになった．溶融 速度の面からみて, 伝熱面としてプレートの両面を 使らことは有効であった. 今回押出最大圧力 9.5 $\mathrm{MPa}$ あるいは押出し流量 $95 \mathrm{~g} \cdot \mathrm{min}^{-1}$ の範囲で安定 な押出しが可能であった. さらに漏れ防止, 性能フッ プには冷却部分と加熱部分を所望の条件で放格に設定 できることが不可欠である．また本装置ではフライト を越えた逆流が存在するので滞留時間が長くなり, 混 練はよくなると期待される。

以上の検討結果を踏を兄て，今後の課題はやはり十 分大きな圧力を発生させ，乙かも漏れのない装置の開 発である. 具体的には次の案が考えられる. 1 枚の可 動ディスクの両面に，互いに逆方向のスパイラル状の チャンネルを彫りこれを团む形で密閉型の固定フラ ットプレートを備える. また，ディスクを輪切りにし て2 部分に分け，各々を加熱部，冷却部とし，その間 に断熱剤を入れて 熱の有効利用を行うことなどであ る.

\section{Nomenclature}

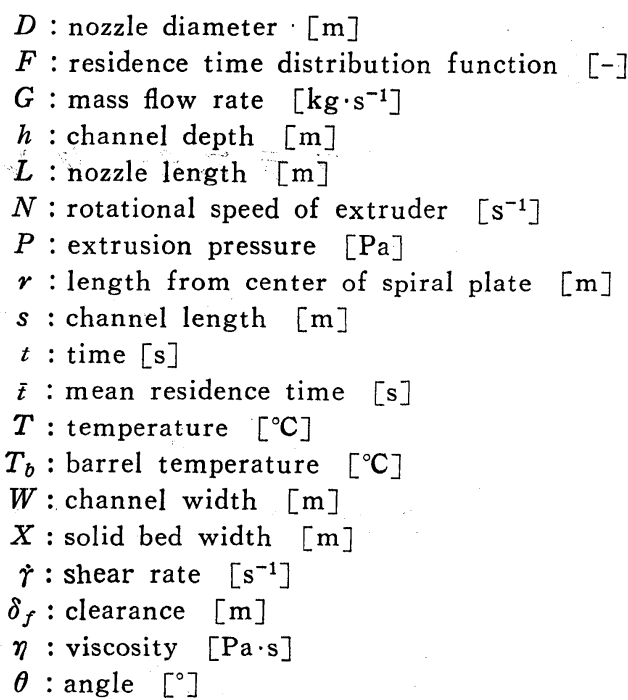

\section{参 考 文 献}

1) Tadmor, Z. and Klein, I.: Engineering Principles of Plasticating Extrusion (1970), Van Nostrand

2) Maxwell, B. and Scalora, A. I.: Modern Plastics, 37, 107 (1959)

3）ルドー・クロード：特許公報 昭 45-2992

4）ルドー・クロード：特許公報 昭 48-4180

5）新本実美：特許公報 昭 40-25071

6) Krein, H. L. and Plumtree, A.: Polym. Eng. Sci., 25, 295 (1985)

7) Tadmor, Z., Hold, P. and Valsamis, L.: Plastics Eng., 35, 20 (1979)

8) Chung, C.I.: Modern Plastics, 9, 178 (1968)

9) Donovan, R. C.: Polym. Eng. Sci., 5, 247 (1971) 